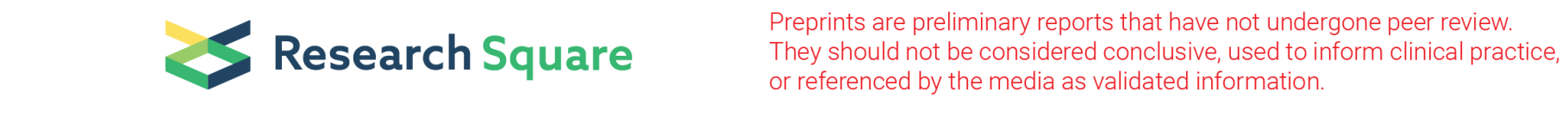

\title{
Investigation on COVID-19 Infection Cases in Korea
}

Yun Jung Kang ( $\sim$ lvpig@naver.com )

Department of Clinical Laboratory Science, Sang-ji University, Wonju 26339, Korea

\section{Case Study}

Keywords: COVID-19, Glove, Large groups, Massive infection, Mask, Prevent

Posted Date: March 24th, 2020

DOl: https://doi.org/10.21203/rs.3.rs-18483/v1

License: @ (1) This work is licensed under a Creative Commons Attribution 4.0 International License. Read Full License 


\section{Abstract}

On December 31st, 2019, the Chinese government announced officially that the country had a pneumonia case with an unknown cause. After that, Korea had 24 confirmed cases on February 8th, and the number has increased constantly since then. COVID-19, a highly contagious virus, infected another patient, Case No. 31, in Daegu; she was the first patient related to Sincheonji Church in Daegu. Later, the number of cases involved with Sincheonji skyrocketed. On March 6th, 2020, the accumulated number of confirmed cases was 6,284, with 42 dead among them. This study, through collecting epidemiological data about various COVID-19 infection cases, found out that getting together in large groups and religious ceremonies leads to massive infection, and that paying close attention to personal hygiene by wearing masks and sanitary gloves, etc., can prevent the spread of COVID-19. Additional epidemiological data and related studies on COVID-19 infections in Korea might either support or modify this conclusion. However, this study is significant in that it emphasizes the precautionary principle in preventing and managing infectious diseases, and that it has a suggestion for public health policies which are on urgent demand currently.

\section{Introduction}

On December 31st, 2019, the Chinese government announced officially that the country had a pneumonia case with an unknown cause. It is not clear when this first case of the new infectious disease occurred. According to what the medical teams in Wuhan, China, reported on 41 confirmed cases (December 1st, 2019- January 2nd, 2020), the first patient developed symptoms on December 1st, but had never visited Huanan fish market [1]. Later, on January 7th, 2020, the Chinese government reported a new kind of corona virus as the cause of this pneumonia case and provided the information on the virus to researchers around the world [2]. WHO named the virus COVID-19 temporarily, but as the English name is rather long in Korean, Korean government decided to call it "Corona 19 (Corona il-gu)," following the opinion of Korea Centers for Disease Control and Prevention [3].

Corona virus (CoV) is a virus which can infect humans and other various animals. It is an RNA virus with gene sizes from 27 to $32 \mathrm{~kb}$, with four genera (alpha, beta, gamma, and delta). Alpha and beta genera can infect humans and animals, while gamma and delta genera infect only animals other than human beings. As implied by its name, the shape of the virus observed through an electron microscope is a crown shape with characteristic protein spikes attached to a ball. The pathogen is COVID-19 and the source of infection is estimated to be an animal, although the investigation is still going on. The infection route channel is estimated to be an animal $\rightarrow$ human $\rightarrow$ human. Spread between humans are assumed to be due to droplet infection. Secondary infection cases in households and hospitals are confirmed. Clinical manifestations are fever, respiratory symptoms (coughs and dyspnea), and pneumonia [4].

The first death from COVID-19 was reported on January 10th in China. On January 13th, 2020, Thailand reported the first case outside of Chinese boundary. The patient never visited the fish market in Wuhan. After that, Japan reported the first case in its territory on January 15th, 2020. Korea followed case on January 20th. On February 8th, the confirmed cases in Korea reached 24 , and the number of patients is still increasing [5]. COVID-19, with is strong infectivity, infected Case No. 31 in Daegu. Korea Centers for Disease Control and Prevention reported Case No. 31 of COVID-19 at 10:00 am, February 18th, 2020. A female in her 60's living in Daegu, Case No. 31 was found to be admitted to a hospital in Daegu at the time. She has attended to a service in Sincheonji Church in Namgu, Daegu, on February 9th and 16th, 2020, each for two hours [6]. After this first confirmed case of Sincheonji Church in Daegu (Case No. 31), the proportion occupied by the Sincheonji believers in Korea increased sharply. On March 6th, 2020, the accumulated number of confirmed cases is counted to be 6,284, with 42 deaths among the patients (Table 1). Korean government, based on the church member registry of 244,743 believers it acquired from Sincheonji authorities, analyzed the connection between the church members and 4,212 COVID-19 cases confirmed until March $2 n d$. According to the analysis, $93 \%$ of the confirmed cases were related to Sincheonji [7]. The possibility of massive infection in church services was suggested. As more than 6,000 COVID-19 cases were confirmed, the cases of infection became diverse. 
This study tries to collect and study various cases of COVID-19 infections until now to figure out measures of prevention against the spread of the disease, while suggesting a managerial direction for public health, which is in urgent demand now.

\section{The Occurrence Types Of Covid-19: Massive Infections}

\section{Sincheonji Church in Daegu}

Nationally, $71.7 \%$ of the confirmed COVID-19 cases in Korea are verified to be related to massive infections. The other $28.3 \%$ cases are due to sporadic infections or still being investigated for the causes. Investigating the massive infection cases by regions, confirmed that cases related to Sincheonji Church in Daegu accounted for $72.4 \%$ of the overall confirmed cases in the city with the number of 3,397 . More cases were confirmed in public and medical facilities while investigating people who had had contact with the Sincheonji followers [8].

\section{Oncheon Church}

In Busan and Gyeongnam, the number of COVID-19 confirmed cases related to a retreat to Oncheon Church is 35. People from Busan account for most of the cases with the number of 33; people from Gyeongnam are the next. Among them, members of the congregation are 28 , and they have infected 7 others who contacted them. The Oncheon Church case occupies $35.5 \%$ of the total confirmed cases in Busan, 93 being the city's total number of patients [9].

\section{Geochang Church}

Geochang Church bore the most COVID-19 confirmed cases as a single group in a single region of Gyeongnam province. Therefore, Gyeongnam province government sent an epidemiological investigation team to Geochang and started an in-dept investigation in cooperation with the city government of Geochang. The number of the members of Geochang Church congregation is 60, with 39 people living in Geochang and 21 coming from other towns. Among the 39 members from Geochang, 10 people were confirmed to be infected while the other 29 were confirmed negative. 62 people who had contacted the confirmed cases are all confined in their own homes [10].

\section{Pilgrims to Israel}

Among the 39 pilgrims of Andong, Gyeongbuk parish of the Catholic Church, who had participated in the pilgrimage to Israel, 30 people were confirmed to be infected by COVID-19. 19 other people who had contacted with the confirmed cases were also tested to be positive, making the total number of the confirmed cases 49. As some of the pilgrims are reported to have visited restaurants and eateries after returning to Korea, there is a possibility of regional spread [11].

\section{Saengmyeongsam Church in Suwon}

The massive infection among Saengmyeongsam Church congregation, which bore 10 confirmed cases of COVID-19, is reported to have been caused by worshipping and eating together in a small and crowded indoor environment. A Sincheonji believer and lecturer from Sincheonji Church, Daegu, who attended the service, is indicated to be the route channel [12].

\section{Daenam Hospital in Cheongdo}

Total of 118 COVID-19 cases were confirmed among the patients and medical personnel of Daenam Hospital in Cheongdo, Gyeongbuk. This is the second biggest massive infection case, following the Sincheonji Church case. As many as seven people died. Among the confirmed cases other than the dead, 101 out of the 103 inpatients of the psychiatric ward were infected, leaving only 2 patients unaffected [13].

\section{St. Mary's Hospital in Eunpyeong-gu, Seoul}


The number of COVID-19 confirmed cases related to St. Mary's Hospital in Eunpyeong-gu, Seoul, increased to 14. The quarantine officials regard this case as the biggest massive infection in Seoul and continuing investigation. Among the 14 confirmed cases, 4 are inpatients, 5 are family members of the patients, 2 are caregivers, 1 is a transferring agent, and 2 are others (a care worker and a blood-donation bus worker). Classifying according to their residences, 6 live in Eunpyeong-gu, 2 in Gangdong-gu, 2 in Jongro-gu, 2 in Seodaemun-gu, 1 in Yangcheon-gu, and 1 in Goyang-si [14].

\section{Hanmaeum Hospital in Changwon}

Hanmaeum Hospital in Changwon, where medical personnel were confirmed positive of COVID-19 subsequently, is the first place quarantined as a cohort. Total number of the confirmed cases is 7 . On February $26^{\text {th }}, 2020$, provincial government of Gyeongsangsnam-do announced that it had decided to quarantine the hospital as a cohort for 14 days after negotiating with the Korea Centers for Disease Control and Prevention, recognizing the seriousness of this situation. The number of people cohort-quarantined is 100, including 91 inpatients and medical personnel [15].

\section{Jaesaeng Hospital in Bundang}

A massive infection occurred among eight medical personnel and inpatients in Jaesaeng Hospital in Bundang, Sengnam-si in Gyeonggi-do. Total of eight cases including 2 nurses, 3 nurses' aides, and 3 patients were confirmed to be positive in COVID19 diagnostic checks [16].

\section{Mil-al Sarang-eu-Jib, a Facility for People with Serious Handicaps in Chilgok}

On February 25th, 2020, 22 confirmed cases of COVID-19 occurred in a facility for people with serious handicaps in Gasanmyeon, Chilgok-gun in Gyeongbuk. According to the public health authorities and the provincial government of Gyeongsangbuk-do, 21 people were confirmed to be infected by COVID-19, including 11 inpatients, 5 staff, and 5 challenged workers in Mil-al Sarang-eu-Jib, a facility for people with serious handicaps, With another case confirmed the day before, the total number of cases is 22 [17].

\section{Seorin Sanitarium in Gyeongsan}

Another massive infection case of Seorin sanitarium with 13 confirmed cases of COVID-19 is also reported to have started with the first patient who had contacted a Sincheonji Church member [18].

\section{Pureun Sanitarium in Bongwha, Gyeongbuk}

Confirmed cases of COVID-19 in Pureun Sanitarium are 49, with 39 inpatients, 9 care workers, and 1 nurse's aide. 116 people live in or work for Pureun Sanitarium, with 56 inpatients, 42 in-house staff, and 18 workers of the day care center. The proportion of confirmed cases reach $42.2 \%$ among the in-house staff [19].

\section{Zumba Dance Studios}

The second confirmed case in Cheonan, Chungnam, a zumba dancer in her 50's, gave lessons to others in three separate studios in the city. Later, 80 cases were confirmed from 7 sports facilities in Chungnam, with zumba dance studios in Cheonan at the center. Among them, 4 are instructors, 50 are attendee, and 26 are family members and other contacts [20].

\section{An Apartment Building in Seongdong-gu}

13 cases of COVID-19 occurred in an apartment building with stores on the ground floor in Seongdong-gu, Seoul. The route channel is estimated as the residents of the building $\rightarrow$ a member of the managerial staff $\rightarrow$ his family members $\rightarrow$ colleagues of the family members [21].

\section{A Private Educational Institute}

Page $4 / 10$ 
As a series of COVID-19 infection cases are occurring in a private educational institute in Busan, Busan Office of Education (with superintendent of education Seokjun Kim) took measures, including sending text messages to all parents of students attending kindergartens, elementary schools, middle schools, and high schools, pleading them not to send their children to private educational institutes until the spread of COVID-19 moderates. Currently, 4 cases were confirmed (including 2 students) from a private educational institute in Jingu, Busan [22].

\section{A Coin Karaoke in Changnyeong}

During the recent week, as many as 6 cases of COVID-19 infection were confirmed from a coin Karaoke in Changnyeong-eup, Changnyeong-gun, Gyeongnam. They are Cases No. 51 (61, female), 56 (30, male), 61 (30, male), 70 (24, male), 71 (16, female), and $76(24$, male). Case No. 51 is the manager of the coin karaoke, while four among the others (Cases No. 61, 70, 71, and 76) were visitors to the place [23].

\section{The Occurrence Types of COVID-19: Sporadic Infections}

\section{Home}

Among the COVID-19 confirmed cases in Korea, two were confirmed tertiary infection cases following secondary infection, spreading social anxiety. A, Case No. 6 (55), was confirmed to have been infected after eating together with B, Case No. 3 (54) in a restaurant (Hanil-gwan) in Gangnam-gu, Seoul. A infected two of his family members, leading to the first tertiary infection cases in Korea. Until now, the number of contacts to A is investigated to be 8, including his family [24].

\section{Wedding Hall}

A, a confirmed case who is currently being treated in a management ward, reported that he was infected after visiting a wedding hall in Daegu. He spent only 1 hour and 10 minutes in the wedding hall. On the date of visiting, his wife and son wore masks unlike himself 25].

\section{Elevator}

A (53, male), a curate of Myeongseong Church in Gangdong-gu, and B (41, female), a resident of the same apartment building he lived in took the same elevator, and both were confirmed positive. B didn't wear a mask in the elevator and became a COVD-19 case occurring from a short time spent in an elevator [26].

\section{Internet café}

In Busan, a middle school student (teenager) was confirmed to be infected by COVID-19 on February 28th, 2020, after visiting the same Internet café where a member of Oncheon Church had visited [27].

\section{Cases of Preventing the Spread of COVID-19}

\section{Daily record of COVID-19}

A, a tour guide, confined himself in his own home when he first developed symptoms such as sore throat on January 31 st, 2020. Since then, he recorded his symptoms meticulously in a daily journal about COVID-19. When going to hospitals, he avoided using public transportation and walked, passing only uncrowded routes. He wore masks and gloves even in his home, which led to the negative confirmation of 23 people who had contacted him, including his mother living with him under the same roof [28].

\section{Home Confinement}

Patient number 63 from Bukgu, Busan, who is in his 30's, confined himself to his home when he heard that he was confirmed positive of COVID-19 and drove by himself even when visited the selective care center. He always wore masks in his own 
home and separated his living area, saving his parents; they were both confirmed negative [28].

\section{Masks and Sanitary Gloves}

A COVID-19 confirmed case C (58, male) wore masks and sanitary gloves even in his homes when he developed symptoms of the virus. He sterilized the dishes he used in hot water right after using. Even though he was confirmed negative once, he recorded his symptoms and the places he went just in case. After he was confirmed, he provided this information to the prevention authorities and contributed to their quick reaction [29].

Pyeongtaek city government in Gyeonggi-do announced that all the family members of the second COVID-19 confirmed case were confirmed negative of the virus on February 24th, 2020. CCTV footages showed that the patient always wore the mask [30].

\section{Conclusion}

Most COVID-19 cases were related to massive infections. According to Korea Centers for Disease Control and Prevention, $71.7 \%$ of COVD-19 cases in Korea are related to massive infections. The other $28.3 \%$ of the cases were related to sporadic infections or still being investigated for the cause [8]. This study agrees in that most cases are related to massive infections (Fig 2). Locations of massive infections are churches, hospitals, sanitariums, private educational institutes, and dance studios, where many people gather in a closed and crowded environment and tend to contact each other at a close distance. Chinese National Hygiene and Health Committee admitted the possibility of infection through aerosols in its 6th edition of COVID-19 Treatment Guide, provided "long-time exposures to dense aerosol in relatively closed environment" [31]. Aerosol means solid or liquid small particles floating in the air, ranging from $0.001 \mu \mathrm{m}$ to $100 \mu \mathrm{m}$ [32]. According to scientific definitions, small particles which can travel far distances for a long time are classified as airborne, while bigger aerosols are classified as droplets [33]. This means that the spread through aerosols can manifest in two types, one being droplet infection by direct contact and one being airborne spread. Generally, droplet infection occurs when the infectee sneezes, coughs, talks, or exhales; this is called the first aerosolization [34]. In contrast, airborne spread is due to the spread of droplet nuclei with the size of $<5 \mu \mathrm{m}$, left behind when the water in droplets evaporates. As the droplet nuclei are light and can float in the air for a long time, they can be especially dangerous [35]. Although religious services conducted in crowded spaces like churches and temples are vulnerable to infections, there are no specific prevention guides from the government. Most churches hosted services as usual, despite the possibility of regional infection with more and more cases of COVD-19 cases being confirmed. Contacts between hundreds and thousands of the members in a same space were inevitable, making people vulnerable to COVID-19 with its strong infectivity. Furthermore, Korea Centers for Disease Control and Prevention suggests the possibility of limited but constant spread in groups through holiday services and small meetings [36]. Private educational institutes and physical training facilities bear similar dangers. Even though the government postponed the starting of the semesters of kindergartens, elementary schools, middle schools, high schools, and universities for fear of massive infections, many private educational institutes and physical training centers are insisting on operation, threatening COVID-19 prevention. According to a report on March 6th, 2020, by the provincial government of Gyeonggi-do and Gyeonggi Office of Education, only 9,932 among 33,091 private educational and training facilities closed on March 4th, with the close rate of $30 \%$. This means that 23,159 facilities, or $70 \%$ of the total institutes, are still running. For their incompliance to the strong government measures of postponing the start of official semesters, the threat of COVID-19 infection and spread is increasing dramatically. The Offices of Education cannot force private institutes to cease operation as there are no legal basis. Voluntary cooperation is desperately needed [37].

There are even cases against the explanation of Chinese National Hygiene and Health Committee's 6th edition of COVID-19 Treatment Guide, which says that the condition for spread through aerosol is "long-time exposures to dense aerosol in relatively closed environment" [32]. The cases of infection in the elevator and the wedding hall, where the patients spent only a short amount of time prove it false. The patients of these two cases are similar in that they didn't wear masks. From the perspective of prevention and management, blocking the route of airborne infection is critical. 
There were also many desirable cases where the infection was prevented by using masks and sanitary gloves [28-30].

Patients, after feeling their symptoms or finding out that they had had contacts with confirmed cases, confined themselves to their homes and shunned crowded places to prevent infecting others. They always wore masks and sanitary gloves, allowing their family members under the same roof and allowed them to be confirmed negative. In contrast, when the confirmed cases didn't wear masks or confirmed themselves in separate rooms in their homes, all their family members were diagnosed to be positive [24]. These are cases where masks and individual hygiene decided the outcome of prevention.

The temporary conclusion of this study based on limited epidemiological data and information on confirmed cases currently available is that group meetings and religious services lead to massive infections of COVID-19, and that caring for individual hygiene by wearing masks and sanitary gloves can prevent its spread. This conclusion can be supported or modified according to additional epidemiological data and research results on COVID-19 infections in Korea. However, this study is meaningful in that it emphasizes the precautionary principle in preventing and managing infectious diseases, and that it has a suggestion for public health, which is in urgent demand currently.

\section{Declarations}

\section{Ethics approval and consent to participate}

Not applicable.

\section{Consent for publication}

Consent for publication was included in the consent to participate form.

\section{Availability of data and materials}

The datasets used and/or analyzed during the current study are available from the corresponding author on reasonable request.

\section{Competing interests}

The authors declare that they have no competing interests.

\section{FUNDING}

None.

\section{Authors' contributions}

The author (YJ Kang) wrote the entire manuscript and holds final responsibility for the decision to submit the manuscript for publication. The author read and approved the final manuscript.

\section{ACKNOWLEDGEMENTS}

None.

\section{References}

1. Huang C, Wang Y, Li X, Ren L, Zhao J, Hu Y et al (2020) Clinical features of patients infected with 2019 novel coronavirus in Wuhan, China. The Lancet 395, 497-506.

2. Carlos WG, Dela Cruz CS, Cao B, Pasnick S, Jamil S (2020) Novel Wuhan (2019-nCoV) Coronavirus. Am J Respir Crit Care Med 201, 7-8. 
3. Korea Centers for Disease Control and Prevention. ; 2020 Feb 12 [cited 2020 Mar 6]. Available

From:http://ncov.mohw.go.kr/tcmBoardView.do?

brdld=\&brdGubun=\&dataGubun=\&ncvContSeq=352840\&contSeq=352840\&board_id=140\&gubun=BDJ (Korean).

4. Korea Centers for Disease Control and Prevention. ; 2020 Feb 4 [cited 2020 Mar 6]. Available

from:http://ncov.mohw.go.kr/baroView.do?brdld=4\&brdGubun=\&dataGubun=\&ncvContSeq=\&contSeq=\&board_id= (Korean).

5. Yoo JH, Hong ST (2020) The Outbreak Cases with the Novel Coronavirus Suggest Upgraded Quarantine and Isolation in Korea. Journal of Kreran Medical Science35(5), e62. DOI https://doi.org/10.3346/jkms.2020.35.e62

6. Park JY. "Corona Corresponds to Korea, Being Caught by Sinchon and Conservatives". New 1; 2020 Feb 29 [cited 2020 Mar 6]. Available from: https://www.news1.kr/articles/?3858187 (Korean).

7. Lee DH. The government "93\% of confirmed people are infected with Sinchonji" President Moon "Pracial ctions". Hankookllbo; 2020 Mar 6 [cited 2020 Mar 6]. Available from: https://www.hankookilbo.com/News/Read/202003031736056042?did=NA\&dtype=\&dty.pecode=\&prnewsid= (Korean).

8. Kim YS. $66 \%$ of Korean corona19 confirmed 'cold infection'... The largest is Shincheon Daegu Church. Yunhap News; 2020 Mar 6 [cited 2020 Mar 6]. Available from: http://ncov.mohw.go.kr/tcmBoardView.do? brdld=\&brdGubun=\&dataGubun=\&ncvContSeq=353407\&contSeq=353407\&board_id=140\&gubun=BDJ (Korean).

9. Lee IJ. Corona 19 group occurrence related to Busan Hot Spring Church... "33 Busan, 2 Gyeongnam". Newsis; 2020 Mar 4 [cited 2020 Mar 6]. Available from: http://www.newsis.com/view/? id=NISX20200304_0000942559\&cID=10201\&pID=10200 (Korean).

10. Choi SW. Epidemiological Survey of Geochang Churches in Korea. Hankyoreh; 2020 Mar 1 [cited 2020 Mar 6]. Available from: http://www.hani.co.kr/arti/area/yeongnam/930480.html\#csidx24193ae36de2947860f94a1947020fc (Korean).

11. You YK. Zumba · Pilgrimage · Hospital Community Outbreaks "Another primer". SBS News; 2020 Mar 4 [cited 2020 Mar 6]. Available from: https://news.sbs.co.kr/news/endPage.do?news_id=N1005680958\&plink (Korean).

12. Jwa SH. Suwon City, 199 members of Life Sam Church. 10 confirmed. Sport News; 2020 Mar 5 [cited 2020 Mar 6]. Available from: http://www.sportsseoul.com/news/read/890904 (Korean).

13. Hwang MG. Subsequent hospital infections occur... Concerns about aralysis of local health care system. Chosun News; 2020. Mar 6 [cited 2020 Mar 6]. Available from: http://news.chosun.com/site/data/html_dir/2020/03/06/2020030601263.html (Korean).

14. Park SW. Eunpyeong St. Mary's Hospital Confirmed by 14... "The Biggest Seoul Outbreak". Kookmin Daily; 2020 Feb 27 [cited 2020 Mar 6]. Available from: http://news.kmib.co.kr/article/view.asp?arcid=0014290920\&code $=61121111 \& c p=n v$ (Korean).

15. Choi HY. Confirmation of 3 medical staffs, 14 days of quarantine. Nocut News;2020 Feb 26 [cited 2020 Mar 6]. Available from: https://www.nocutnews.co.kr/news/5297314 (Korean).

16. Jang CS. Medical staff at Bundang Jesaeng Hospital and 8 patients Corona 19 'Group infection'. Financial News; 2020 Mar 6 [cited 2020 Mar 6]. Available from: https://www.fnnews.com/news/202003060851165609 (Korean).

17. Jo JH. Chilgok Severe Disability Facility 'Millal House', Corona 19 Confirmed by 22. Ohmy News; 2020 Feb 25 [cited 2020 Mar 6]. Available from: http://www.ohmynews.com/NWS_Web/View/at_pg.aspx?

CNTN_CD=A0002615537\&CMPT_CD=P0010\&utm_source=naver\&utm_medium=newsearch\&utm_campaign=naver_news (Korean).

18. Jo Tl. Gyeongsangbuk-do, more than half of new patients. Nocut News; 2020 Mar 6 [cited 2020 Mar 6 ]. Available from: https://www.nocutnews.co.kr/news/5302864 (Korean).

19. Kim HJ. Second South Hospital Hospital situation Ona... Bonghwa Blue Sanitarium 49 Infections. Yunhap news; 2020 Mar 6 [cited 2020 Mar 6]. Available from: https://www.yna.co.kr/view/AKR20200306078300053?input=1195m (Korean). 
20. Kim JL. Worried that the dance instructor confirmed by Corona19 in Cheonan will become a local super evangelist. Korea Economic TV; 2020 Feb 26 [cited 2020 Mar 6]. Available from: http://news.wowtv.co.kr/NewsCenter/News/Read? articleld=A202002260003\&t=NN (Korean).

21. Chai YT. '114 quarantines' 13 confirmed people related to the apartment in Seongdong-gu. Hankyoreh News; 2020 Mar 5 [cited 2020 Mar 6]. Available

from: http://www.hani.co.kr/arti/area/capital/931269.html\#csidx5612c2e04c7f6c29a593c415479d4b0 (Korean).

22. Park CH. We are frustrated with school infection spread... Busan Office of Education appeals to parents. Nocut News; 2020 Mar 4 [cited 2020 Mar 6]. Available from: https://news.naver.com/main/read.nhn? mode $=$ LSD\&mid $=$ sec\&oid $=079 \&$ aid $=0003331693 \&$ sid $1=001$ (Korean).

23. Choi SW. Chang-nyeong The sixth person who confirmed coin karaoke... Small scale infection is a reality. Hankyoreh; 2020 Mar 5 [cited 2020 Mar 6]. Available from:http://www.hani.co.kr/arti/area/yeongnam/931259.html\#csidxf236db327f93a94baaedf47a34f20f1 (Korean).

24. Kim JY. 'Confirmation No. $3 \rightarrow$ No. $6 \rightarrow 2$ Family' 3 cases of infection in Korea. World Daily; 2020 Jan 31 [cited 2020 Mar 6]. Available from: https://m.post.naver.com/viewer/postView.nhn? volumeNo=27398212\&memberNo=15305315(Korean).

25. Lee HR. Corona 19 Confirmation "Don't be Attentive in 1 Hour of Daegu Wedding". Seoul Economy; 2020 Mar 4 [cited 2020 Mar 6]. Available from:https://news.naver.com/main/read.nhn? mode $=$ LSD\&mid $=$ sec\&oid $=011$ \&aid $=0003704356 \&$ sid $1=001$ (Korean).

26. Son BG. Elevator lifted without mask, 'Corona 19' confirmed. Ohmy News; ; 2020 Feb 28 [cited 2020 Mar 6]. Available from:https://news.naver.com/main/read.nhn?mode=LSD\&mid=sec\&oid=047\&aid=0002258833\&sid1=001 (Korean).

27. Kim YD. Where do Youth Acting School?... 'PC · Karaoke' in various places. KBS News; 2020 Mar 6 [cited 2020 Mar 6 ]. Available from: http://news.kbs.co.kr/news/view.do?ncd=4395691\&ref=A(Korean).

28. Kim JH. "Never go to harm"... 'Corona journal' with few copper wires and symptoms. JTBC News; 2020 Mar 4 [cited 2020 Mar 6]. Available from: http://news.jtbc.joins.com/article/article.aspx?news_id=NB11938298 (Korean).

29. Im DW. Wearing masks and hygiene gloves at home... Carefully record the symptoms and movement. International Newspaper; 2020 Mar 2 [cited 2020 Mar 6]. Available from: http://www.kookje.co.kr/news2011/asp/newsbody.asp? code $=0300 \&$ key $=20200303.22003001028$ (Korean).

30. Kang YH. Pyeongtaek's 2nd Corona 19 Confirmed Family 'Negative'. yunhap News; 2020 Feb 24 [cited 2020 Mar 6]. Available from: https://news.naver.com/main/read.nhn?mode=LSD\&mid=sec\&oid=001\&aid=0011424175\&sid1=001 (Korean).

31. Jung YH. Chinese Authorities Add Coronal 19 Disturbance Path "Aerosol Formation". KBS News; 2020 Mar 4 [cited 2020 Mar 6]. Available from: http://news.kbs.co.kr/news/view.do?ncd=4393978\&ref=A (Korean).

32. Hinds W Aerosol technology: properties, behavior, and measurement of airborne particles. 2nd ed. New York: Wiley; 1999.

33. Aliabadi AA, Rogak SN, Bartlett KH, Green SI (2011) Preventing airborne disease transmission: review of methods for ventilation design in health care facilities, Adv Prev Med 2011, 1-21.

34. La Rosa G, Fratini M, Della Libera S, laconelli M, Muscillo M (2013) Viral infections acquired indoors through airborne, droplet or contact transmission. Ann Ist Super Sanita, 49, 124-132.

35. Fernstrom A (2013) Goldblatt M Aerobiology and its role in the transmission of infectious diseases, J Pathog, 2013, 1-13.

36. Korea Centers for Disease Control and Prevention. Coronavirus Infection-19 Domestic Outbreaks (February 22); 2020 Feb 24 [cited 2020 Mar 6]. Available from: http://ncov.mohw.go.kr/tcmBoardView.do? brdld=\&brdGubun=\&dataGubun=\&ncvContSeq=353050\&contSeq=353050\&board_id=140\&gubun=BDJ (Korean).

37. Lee C. Postponement of school opening, 'combination', and teaching instructors... Outbreak 'emergency'. Nocut News; 2020 Mar 6 [cited 2020 Mar 6]. Available from: https://www.nocutnews.co.kr/news/5303397 (Korean).

\section{Table}


Table 1. The present condition of COVID-19 occurrences in Korea (00:00, March $6^{\text {th }}$ )

\begin{tabular}{|c|c|c|c|c|c|c|c|c|}
\hline \multirow[t]{2}{*}{ Category } & \multirow[t]{2}{*}{ Sum } & \multicolumn{4}{|c|}{ Present confirmed case conditions } & \multicolumn{3}{|c|}{ Present test conditions } \\
\hline & & Sum & $\begin{array}{l}\text { Lifted } \\
\text { Quarantine }\end{array}$ & Quarantined & Deaths & Sum & Tested & $\begin{array}{l}\text { Confirmed } \\
\text { negative }\end{array}$ \\
\hline \multirow{2}{*}{$\begin{array}{l}\text { 00:00 03/05 } \\
\text { (Thu) }\end{array}$} & & & 88 & & & & & \\
\hline & 146,541 & 5,766 & & 5,643 & 35 & 140,775 & 21,810 & 118,965 \\
\hline 00:00 & 164,740 & 6,284 & 108 & 6,134 & 42 & 158,456 & 21,832 & 136,624 \\
\hline \multicolumn{9}{|l|}{ 03/06 } \\
\hline \multicolumn{9}{|l|}{ (Fri) } \\
\hline \multirow[t]{2}{*}{ Fluctuations } & $+18,199$ & +518 & & & & & & $+17,659$ \\
\hline & & & +20 & +491 & +7 & $+17,681$ & +22 & \\
\hline
\end{tabular}

\section{Figures}

\section{Figure 1}

Distribution of COVID-19 occurrence types. 